\title{
PENGARUH PELATIHAN EMPATI MELALUI KARTU EKSPRESI EMOSI TERHADAP PERILAKU MENOLONG DAN PERILAKU AGRESIF PADA ANAK PRASEKOLAH
}

\author{
Indah Fajrotuz Zahro \\ Bimbingan Konseling Islam, STAI Attanwir Bojonegoro \\ Jl. Raya Talun No.220 Desa Talun, Kecamatan Sumberrejo, Bojonegoro \\ Telp. 0856-4985-0916; Fax. 0353331610 \\ E-mail: indahfajrotuzzahro@gmail.com
}

\begin{abstract}
This study aims to determine the effect of empathy training through emotional expression cards on helpful behavior and aggressive behavior in preschool children. The subjects of this study are the group B children of Bina Anak Sholeh kindergarten Tuban. It uses purposive random sampling technique. A total of 28 children were sampled and divided into 14 children as experimental and control group. The instruments used are image tests of helpful behavior and aggressive behavior. Data were analyzed by using Mann Whitney U Test to test two independent samples using SPSS 16 for windows. From the data analysis, it is known that hypotheses 1, 2, and 3 are accepted, namely 1) The positive effect of empathy training through emotional expression cards on helpful behavior and aggressive behavior in experimental and control group; 2) The positive effect of empathy training through emotional expression cards on helpul behavior of preschool children; 3) There is a negative effect of empathy training through emotional expression cards on aggressive behavior of preschool children.
\end{abstract}

Keywords: Empathy, Emotional Expression Cards, Helpul Behavior, Aggressive Behavior.

\section{Pendahuluan}

Ketika berada dalam kondisi emosi, seorang individu yang belum matang, biasanya cenderung belum memiliki kontrol yang baik dalam mengelola emosi tersebut. Pada anakanak misalnya, munculnya emosi negatif, seperti marah atau sedih, biasanya dapat menjadi pemicu munculnya sikap atau perilaku yang kurang adaptif. Seorang anak yang belum memiliki pemahaman dan penguasaan emosi yang matang, akan cenderung bersikap sesuai dengan kemampuannya dalam mengekspresikan dan mereduksi emosi negatif yang ia rasakan.

Pada kondisi emosi, anak-anak cenderung belum mampu memperhatikan dan mempertimbangkan norma atau aturan kepantasan yang berlaku dalam hidup bersama. Beberapa perilaku yang kurang adaptif yang seringkali dimunculkan oleh anak-anak ketika ia berada dalam emosi negatif misalnya perilaku tidak jujur, perilaku agresi, maupun perilaku yang tidak mempertimbangkan hak dan kesejahteraan orang lain. ${ }^{1}$

Perkembangan emosi merupakan salah satu aspek perkembangan yang penting untuk diperhatikan pada masa anak-anak. Hal ini karena perkembangan emosi yang baik akan

\footnotetext{
${ }^{1}$ Eisenberg \& Mussen, dalam Dayakisni, T \& Hudaniah, Psikologi Sosial (Malang: UMM Press, 2006)
} 
memungkinkan anak mengenali aspek-aspek emosi dirinya serta dapat mengekspresikan emosi tersebut secara tepat terhadap orang lain maupun lingkungan sekitarnya. Oleh karena itu stimulasi aspek perkembangan emosi untuk mengembangkan penguasaan kecakapan emosional dan kecakapan sosial perlu dilakukan oleh guru maupun orangtua terhadap anak. Hal ini dimaksudkan untuk membantu munculnya pemahaman emosi yang baik, berkembangnya kesadaran diri yang positif, serta mengarahkan anak mencapai pembentukan jati dirinya, sehingga dapat menjalin relasi positif dengan orang lain di lingkungan sekitarnya. $^{2}$

Salah satu hal yang bisa dilakukan oleh orangtua maupun guru untuk mengembangkan aspek sosio-emosional anak yakni dengan melatihkan keterampilan empati sejak dini. Penguasaan keterampilan empati dapat bermanfaat untuk mengatasi masalah agresifitas pada anak, yang mana agresifitas ini merupakan salah satu gejala perkembangan sosio-emosional yang kurang optimal. Mergage dan Brigham ${ }^{3}$ menyatakan bahwa pemberian pelatihan empati akan mengurangi agresi. Menumbuhkan rasa empati dengan melatih pemikiran dan merasakan pikiran dan perasaan orang lain, dianggap mampu mengatasi menurunkan perilaku agresif pada anak.

Penguasaan keterampilan empati juga menjadi salah satu unsur berkembangnya sikap atau perilaku prososial pada individu. Perilaku prososial tersebut meliputi berbagi, kerjasama, menyumbang, menolong, jujur, kedermawanan, dan mempertimbangkan hak dan kesejahteraan orang lain. ${ }^{4}$ Perilaku prososial berfungsi meningkatkan kualitas hubungan sosial antar individu. Selain itu perilaku prososial juga menimbulkan perasaan berharga, bangga atau puas terhadap diri sendiri karena bermanfaat mensejahterakan orang lain. ${ }^{5}$ Bentuk yang paling jelas dari prososial adalah perilaku menolong. ${ }^{6}$

Pelatihan empati dianggap sebagai upaya tepat untuk menumbuhkan rasa empati pada diri seseorang dan pelatihan empati akan memberikan keefektifan untuk mengatasi perilaku agresif jika dilakukan sejak dini. Pelatihan empati dapat dilakukan pada masa awal kanakkanak karena masa anak-anak merupakan masa dimana anak membutuhkan banyak stimulasi dan latihan untuk menjalani proses sosialisasi yang baik pada tahap perkembangan selanjutnya. Ada hubungan antara besarnya empati dengan kecenderungan menolong. Hubungan antara empati dengan perilaku menolong secara konsisten ditemukan pada semua kelompok umur. ${ }^{7}$

Suatu pelatihan dan stimulasi yang dilakukan pada masa awal kanak-kanak tentunya membutuhkan cara yang efektif agar pelatihan tersebut dapat diterima dan dilakukan oleh anak-anak. Perkembangan kognitif yang berada pada masa praoperasional menurut Piaget $^{8}$ menunjukkan bahwa anak belajar menggunakan dan merepresentasikan benda-benda dengan gambar-gambar, kata-kata dan lukisan-lukisan. Anak-anak mulai menjalankan fungsi simbolis

\footnotetext{
${ }^{2}$ Herdina dkk, Psikologi Perkembangan \& Pendidikan Anak Usia Dini (Jakarta: Prenadamedia Group, 2016)

${ }^{3}$ Dayakisni, T \& Hudaniah, Psikologi Sosial (Malang: UMM Press, 2006)

${ }^{4}$ Eisenberg \& Mussen, dalam Dayakisni, T \& Hudaniah, Psikologi Sosial (Malang: UMM Press, 2006)

${ }^{5}$ Eisenberg \& Fabes, dalam Tanaya, K, K \& Farid M, Pengaruh Cerita Moral Terhadap Perilaku Prososial Anak, (Persona, Jurnal Psikologi Indonesia, Vol. 2, 2013), 84-89.

${ }^{6}$ Sabiq, Z \& Djalali, M. A, Kecerdasan Emosi, Kecerdasan Spiritual dan Perilaku Prososial Santri Pondok Pesantren Nasyrul Ulum Pamekasan (Persona, Jurnal Psikologi Indonesia, Vol I, No. 2, 2012), 53-65.

${ }^{7}$ Faturochman, Pengantar Psikologi Sosial (Yogyakarta: Pustaka Book Publishing, 2006)

${ }^{8}$ Massardi, S \& Yudhistira, Pendidikan Karakter dengan Metode Sentra (Jakarta: Esmass, 2012), 41.
} 
dan muncul pemikiran intuitifnya. Menurut Piaget tahap mengaktifkan fungsi simbolis dan munculnya pemikiran intuitif ini merupakan tahap dasar belajar anak melalui imitasi dan bermain, karena anak membangun imaji-imaji simbolik melalui aktivitas yang terinternalisasi. Berdasarkan perkembangan kognitif Piaget tersebut menunjukkan bahwa anak-anak akan lebih mudah mendapatkan informasi melalui media gambar-gambar ekspresi emosi dan katakata yang dikemas dalam bentuk nyanyian serta lagu. Pelatihan empati yang memperhatikan perkembangan kognitif pada masa awal kanak-kanak diharapkan dapat dijalani oleh anakanak dengan baik serta mampu menghasilkan perilaku yang diharapkan.

Hasil akhir yang terbaik dari empati adalah munculnya perilaku menolong. ${ }^{9}$ Jika seseorang telah memiliki rasa empati di dalam dirinya maka ia akan menjadi pribadi yang mampu memahami situasi dan kondisi orang lain hingga menunjukkan perilaku sosial yang positif, seperti perilaku menolong, menemukan pemecahan masalahan yang dihadapi secara tepat dan mencegah timbulnya perilaku agresif.

Lingkungan memegang peran penting pada perkembangan setiap individu. Lingkungan yang kondusif dan demokratis menunjukkan mampu menumbuhkan pribadi yang mampu menghargai orang lain, toleransi dan mampu merasakan perasaan orang lain. Pelatihan yang dilakukan di lingkungan yang tepat dan kondusif akan lebih berhasil dan menunjukkan perubahan perilaku anak ke arah yang positif.

\section{Emosi}

Emosi juga diartikan sebagai perasaan atau afeksi yang timbul ketika seseorang sedang berada dalam keadaan atau suatu interaksi yang dianggap penting olehnya, terutama wellbeing dirinya. ${ }^{10}$ Macam-macam Emosi. Emosi diwakili oleh perilaku yang mengekspresikan kenyamanan atau ketidaknyamanan terhadap keadaan atau interaksi yang dialami. Emosi juga bisa berbentuk sesuatu yang spesifik seperti rasa senang, takut, marah dan seterusnya, tergantung dari interaksi yang dialami. ${ }^{11}$

Menurut Hurlock, ${ }^{12}$ beberapa emosi yang umum pada awal masa kanak-kanak yakni, Pertama, Amarah; Penyebab amarah yang paling umum adalah pertengkaran mengenai permainan, tidak tercapainya keinginan dan serangan yang hebat dari anak lain. Anak mengungkapkan rasa marah dengan ledakan amarah yang ditandai dengan menangis, berteriak, menendang, melompat-lompat atau memukul.

Kedua, Takut; pembiasaan, peniruan dan ingatan tentang pengalaman yang kurang menyenangkan berperan penting dalam menimbulkan rasa takut, seperti cerita-cerita, gambargambar, acara radio, dan televisi, dan film-film dengan unsur yang menakutkan. Pada mulanya reaksi anak terhadap rasa takut adalah panik; kemudian menjadi lebih khusus seperti lari, menghindar, dan bersembunyi, menangis, dan menghindari situasi yang menakutkan.

Ketiga, Cemburu; anak menjadi cemburu bila ia mengira bahwa minat dan perhatian orangtua beralih kepada orang lain di dalam keluarga, biasanya adik yang baru lahir. Anak

\footnotetext{
${ }^{9}$ Taufik, Empati: Pendekatan Psikologi Sosial (Jakarta: PT Rajagrafindo Persada, 2012)

${ }^{10}$ Campos, Saarni, dkk dalam Santrock, J. W, Perkembangan Anak (Jakarta: Erlangga, 2007)

${ }^{11}$ Santrock, J. W, Perkembangan Anak (Jakarta: Erlangga, 2007)

${ }^{12}$ Hurlock, E. B, Psikologi Perkembangan: Suatu Pendekatan Sepanjang Rentang Kehidupan (Jakarta: Erlangga, 2004), 116.
} 
yang lebih muda dapat mengungkapkan kecemburuannya secara terbuka atau menunjukkannya dengan kembali berperilaku seperti anak kecil, seperti mengompol, purapura sakit atau menjadi nakal. Perilaku ini semua bertujuan untuk menarik perhatian.

Keempat, Ingin tahu; Anak mempunyai rasa ingin tahu terhadap hal-hal yang baru dilihatnya, juga mengenai tubuhnya sendiri dan tubuh orang lain. Reaksi pertama adalah dalam bentuk penjelajahan sensorimotorik; kemudian sebagai akibat dari tekanan sosial dan hukuman, ia bereaksi dengan bertanya.

Kelima, iri hati; Anak-anak sering iri hati mengenai kemampuan atau barang yang dimiliki orang lain. Iri hati ini diungkapkan dalam bermacam-macam cara, yang paling umum adalah mengeluh tentang barangnya sendiri, dengan mengungkapkan keinginan untuk memiliki barang seperti dimiliki orang lain dengan mengambil benda-benda yang menimbulkan iri hati.

Keenam, Gembira; anak-anak merasa gembira karena sehat, situasi yang tidak layak, bunyi yang tiba-tiba atau yang tidak diharapkan, bencana yang ringan, membohongi orang lain dan berhasil melakukan tugas yang dianggap sulit. Anak mengungkapkan kegembiraannya dengan tersenyum dan tertawa, bertepuk tangan, melompat - lompat, atau memeluk benda atau orang yang membuatnya bahagia.

Ketujuh, Sedih; anak-anak merasa sedih karena kehilangan segala sesuatu yang dicintai atau yang dianggap penting bagi dirinya, apakah itu orang, binatang, atau benda mati seperti mainan. Secara khas anak mengungkapkan kesedihannya dengan menangis dan dengan kehilangan minat terhadap kegiatan normalnya, termasuk makan. Kedelapan, Kasih Sayang; anak - anak belajar mencintai orang, binatang, atau benda yang menyenangkannya. Ia mengungkapkan kasih sayang secara lisan bila sudah besar, tetapi ketika masih kecil anak menyatakannya secara fisik dengan memeluk, menepuk, dan mencium objek kasih sayangnya.

\section{Empati}

Empati adalah kemampuan untuk menempatkan diri sendiri dalam keadaan psikologis orang lain dan untuk melihat suatu situasi dari sudut pandang orang lain. ${ }^{13}$ Empati juga dapat dipahami sebagai kemampuan "menyelaraskan diri" (peka) terhadap apa, bagaimana dan latar belakang perasaan dan pikiran orang lain sebagaimana orang tersebut merasakan dan memikirkannya. Eisenberg, Batson, Davis, Fesbach, Hoffman, menyatakan bahwa empati terdiri atas dua komponen, kognitif dan afektif. ${ }^{14}$ Selain kedua komponen tersebut beberapa teoritikus lainnya menambahkan aspek komunikatif sebagai faktor ketiga. ${ }^{15}$

Komponen Kognitif merupakan komponen yang menimbulkan pemahaman terhadap perasaan orang lain. Fesbach mendefinisikan aspek kognitif sebagai kemampuan untuk membedakan dan mengenalikan kondisi emosional yang berbeda. Eisenberg \& Strayer menyatakan bahwa salah satu yang paling mendasar pada proses empati adalah pemahaman

\footnotetext{
${ }^{13}$ Ibid

${ }^{14}$ Taufik, Empati: Pendekatan Psikologi Sosial (Jakarta: PT Rajagrafindo Persada, 2012)

15 Ridley \& Lingle, 1996; Bierhoff 2002; dan Wang, dkk, dalam Taufik, Empati: Pendekatan Psikologi Sosial (Jakarta: PT Rajagrafindo Persada, 2012)
} 
adanya perbedaan antara individu (perceiver) dan orang lain. Secara garis besar bahwa aspek kognitif dari empati meliputi aspek pemahaman atas kondisi orang lain. ${ }^{16}$

Kemudian terkait komponen Afektif pada empati ini terdiri atas simpati, sensitivitas, dan sharing penderitaan yang dialami orang lain seperti perasaan dekat terhadap kesulitankesulitan orang lain yang diimajinasikan seakan-akan dialami oleh diri sendiri ${ }^{17}$. Beberapa peneliti mengemukakan bahwa aspek afektif ini tidak dapat dipisahkan dengan aspek kognitif. Para ahli memandang empati sebagai konsep multidimensional yang meliputi komponen afektif dan kognitif secara bersama-sama, ${ }^{18}$ terdiri atas komponen afektif dan kognitif yang tidak dapat dipisahkan, ${ }^{19}$ atau keduanya (kognitif dan afektif) dianggap sebagai satu aspek. ${ }^{20}$

Komponen ketiga dari empati yakni komponen komunikatif. Komponen Komunikatif, menurut Wang dkk, adalah ekspresi dari pikiran-pikiran empatik (intellectual empathy) dan perasaan-perasaan (empathic emotions) terhadap orang lain yang dapat diekspresikan melalui kata-kata dan perbuatan. ${ }^{21}$

\section{Perilaku Menolong}

Perilaku menolong (helping) merupakan bagian dari prososial. Menurut Baron dan Byrne, perilaku prososial adalah suatu tindakan menolong yang menguntungkan orang lain tanpa harus menyediakan suatu keuntungan langsung pada orang yang melakukan tindakan tersebut, dan mungkin bahkan melibatkan suatu resiko bagi orang yang menolong. Perilaku menolong merupakan tindakan yang mempunyai konsekuensi menyediakan beberapa keuntungan atau meningkatkan kesejahteraan orang lain. Perilaku menolong menggambarkan manusia sebagai makhluk yang tidak egois dan dermawan, mampu memberikan perhatian nyata untuk kesejahteraan orang lain ${ }^{22}$.

McGuire mengklasifikasi perilaku menolong menjadi empat jenis ${ }^{23}$, yaitu: (1) Casual helping, melakukan hal-hal kecil yang biasa dilakukan untuk membantu kenalan. Misalnya meminjami pensil kepada kenalan di sekolah, menunjukkan alamat seseorang, dan sebagainya. (2) Substantial personal helping, melakukan sejumlah usaha untuk membantu teman dengan manfaat yang nyata. Misalnya membantu tetangga pindah rumah, menjadi panitia pernikahan, dan sebagainya. (3) Emotional helping, memberikan dukungan personal untuk teman. Misalnya mendengarkan curahan hati kawannya yang sedang bermasalah, memberikan kata-kata positif kepada kawannya yang sedang berduka, dan sebagainya. (4) Emergency helping, memberikan pertolongan kepada orang asing yang sedang mengalami masalah serius. Misalnya bergabung dalam kerelawanan untuk membantu korban bencana alam, membantu korban kecelakaan lalulintas, dan sebagainya.

\section{Perilaku Agresif}

\footnotetext{
${ }^{16}$ Taufik, Empati: Pendekatan Psikologi Sosial (Jakarta: PT Rajagrafindo Persada, 2012)

17 Ibid

${ }^{18}$ Ibid

${ }^{19}$ Ibid

${ }^{20}$ Ibid

${ }^{21}$ Ibid

${ }^{22}$ Baron \& Byrne, Psikologi sosial, Alih Bahasa: Ratna Djuwita (Jakarta: Erlangga, 2005)

${ }^{23}$ Taufik, Empati: Pendekatan Psikologi Sosial (Jakarta: PT Rajagrafindo Persada, 2012)
} 
Menurut Kamus Besar Bahasa Indonesia, Perilaku diartikan sebagai tanggapan atau reaksi individu terhadap rangsangan atau lingkungan ${ }^{24}$. Menurut Berkowitz, Agresi adalah segala bentuk perilaku yang dimaksudkan untuk menyakiti seseorang, baik secara fisik maupun mental. ${ }^{25}$

Perilaku agresif merupakan tingkah laku menyerang baik secara fisik maupun verbal atau baru berupa ancaman yang disebabkan karena adanya rasa permusuhan. Perilaku ini sering muncul sebagai reaksi emosi terhadap frustasi misalnya karena dilarang sesuatu.

\section{Hipotesis}

Hipotesis yang akan diajukan pada penelitian ini adalah:

1. Adanya pengaruh pelatihan empati melalui kartu ekspresi emosi terhadap perilaku menolong dan perilaku agresif pada kelompok eksperimen dan kelompok kontrol.

2. Adanya pengaruh positif pelatihan empati melalui kartu ekspresi emosi terhadap perilaku menolong anak.

3. Adanya pengaruh negatif pelatihan empati melalui kartu ekspresi emosi terhadap perilaku agresif anak.

\section{Metode}

Sampel adalah sebagian atau wakil populasi yang akan diteliti. ${ }^{26}$ Teknik pengambilan sampel yang digunakan pada penelitian ini adalah purposive random sampling. Anak yang menjadi sampel penelitian ini adalah anak-anak yang memiliki karakteristik perilaku menolong kurang dan anak-anak yang memiliki perilaku agresif tinggi berusia $5-7$ tahun. Pengambilan sampel dengan cara observasi dilakukan oleh wali kelas selaku observer dengan menggunakan format observasi perilaku menolong dan perilaku agresif yang terdiri dari 22 aitem.

Penelitian pengaruh pelatihan empati melalui kartu ekspresi emosi terhadap perilaku menolong dan perilaku agresif pada anak usia dini ini terdiri dari variabel eksperimen dan variabel terikat. Variabel eksperimen dalam penelitian ini adalah pelatihan empati melalui kartu ekspresi emosi. Sedangkan variabel terikatnya adalah perilaku menolong dan perilaku agresif.

Pelatihan dilaksanakan selama 8 kali, dengan alokasi waktu 60 menit setiap kali pelaksanaan pelatihan. Kegiatan pelatihan empati dilaksanakan pada tanggal 4 - 13 Juni 2014. Kegiatan pelatihan yang dilaksanakan terdiri dari pemberian informasi mengenai pengertian empati, perilaku menolong dan perilaku agresif yang dikemas dalam lagu. Selain itu terdapat beberapa permainan, yakni yuk berekspresi, puzzle ekspresi, kantung ajaib, pancing ekspresi emosi dan kamera ekspresi. Kegiatan pelatihan terperinci dalam modul pelatihan empati melalui kartu ekspresi emosi yang telah diujikan dengan menggunakan judgement ahli.

Alat ukur perilaku menolong yang digunakan pada penelitian ini adalah tes perilaku menolong. Tes perilaku menolong dikembangkan dari kerangka konsep 9 Pilar Karakter yang dikemukakan oleh Indonesia Heritage Foundation (IHF). Peneliti memilih gambar yang

\footnotetext{
${ }^{24}$ Pusat Bahasa, Kamus Besar Bahasa Indonesia edisi ke- 4 (Departemen Pendidikan Nasional. Jakarta: PT Gramedia Pustaka Utama, 2008), 1056.

${ }^{25}$ Sobur, A, Psikologi Umum (Jakarta: Rajagrafindo, 2000)

${ }^{26}$ S Arikunto, Prosedur Penelitian Suatu Pendekatan Praktik (Jakarta: PT Rineka Cipta, 2006)
} 
sesuai dengan variabel perilaku menolong. Jumlah aitem perilaku menolong sebanyak 36 gambar. Gambar-gambar tersebut mengandung informasi tentang perilaku menolong yang terdiri dari gambar yang favorable dan gambar unfavorable. Teknik pengukuran dalam penelitian ini adalah menggunakan tes obyektif dengan pilihan benar-salah. Kemudian anakanak diminta memberikan tanda checklist pada kolom pilihan jawaban benar atau salah yang telah disediakan. Pada aitem favorable, pilihan benar akan diberikan skor 1 sedangkan pilihan salah diberikan skor 0. Sebaliknya, pada aitem unfavorable, pilihan benar akan diberikan skor 0 sedangkan pilihan salah diberikan skor 1 .

Alat ukur perilaku agresif yang digunakan pada penelitian ini adalah tes perilaku agresif. Tes perilaku agresif dikembangkan dari kerangka konsep 9 Pilar Karakter yang dikemukakan oleh Indonesia Heritage Foundation (IHF). ${ }^{27}$ Peneliti memilih gambar yang sesuai dengan variabel perilaku agresif. Jumlah aitem perilaku agresif sebanyak 36 gambar. Gambar-gambar tersebut mengandung informasi tentang perilaku agresif yang terdiri dari gambar yang favorable dan gambar unfavorable. Teknik pengukuran dalam penelitian ini adalah menggunakan tes obyektif dengan pilihan benar-salah. Kemudian anak-anak diminta memberikan tanda checklist pada kolom pilihan jawaban benar atau salah yang telah disediakan. Pada aitem favorable, pilihan benar akan diberikan skor 1 sedangkan pilihan salah diberikan skor 0. Sebaliknya, pada aitem unfavorable, pilihan benar akan diberikan skor 0 sedangkan pilihan salah diberikan skor 1 .

Jenis penelitian yang digunakan adalah true experiments. Disebut sebagai true experiment karena dalam desain ini peneliti dapat mengontrol semua variabel luar yang mempengaruhi jalannya eksperimen. Jadi validitas internal (kualitas pelaksanaan rancangan penelitian) menjadi tinggi. Sejalan dengan hal tersebut, tujuan dari true experiments menurut Suryabrata, ${ }^{28}$ adalah untuk menyelidiki kemungkinan saling hubungan sebab akibat dengan cara mengenakan perlakuan dan membandingkan hasilnya dengan grup kontrol yang tidak diberi perlakuan.

Desain eksperimen yang digunakan adalah two group posttest only-design. Pada desain ini peneliti memberikan perlakuan pelatihan empati melalui kartu ekspresi emosi pada kelompok eksperimen, sedangkan kelompok kontrol tidak diberikan perlakuan apapun dan mengikuti jadwal kegiatan rutin di sekolah. Setelah itu kedua kelompok (eksperimen dan kontrol) diberikan posttest dengan mengisi lembar tes perilaku menolong dan perilaku agresif untuk mengetahui adanya perbedaan pemikiran dari kelompok eksperimen dan kelompok kontrol.

Teknik analisis yang digunakan untuk menguji hipotesis penelitian ini adalah uji $\mathrm{t}$ nonparametrik. Teknik analisis ini dipilih karena jumlah sampel yang relatif kecil, yakni kurang dari 30. Metode statistik ini tidak memerlukan suatu anggapan tertentu mengenai bentuk sebaran atau parameter yang diselidiki. Karena jumlah sampel yang kurang dari 30 maka tidak diperlukan uji asumsi atau uji prasyarat melainkan langsung dilakukan analisis data.

Pada penelitian ini peneliti menggunakan uji t nonparametrik untuk menganalisis data yang diperoleh. Hal ini karena ukuran sampel kecil yakni sejumlah 28 anak. Metode

\footnotetext{
${ }^{27}$ Indonesia Heritage Foundation, 9 Pilar Karakter (Jakarta: Gapprint, 2010)

${ }^{28}$ Prasetyo, B \& Jannah, L. M, Metode Penelitian Kuantitatif (Jakarta: PT RajaGrafindo Persada, 2007)
} 
nonparametrik memerlukan sedikit asumsi dengan penerapan yang lebih luas, serta kemungkinan digunakan secara salah (karena pelanggaran asumsi) lebih kecil daripada metode parametrik. Uji nonparametrik yang digunakan adalah Mann Whitney U Test untuk menguji dua sampel independen dengan menggunakan bantuan program SPSS 16 for windows.

\section{Hasil dan Pembahasan}

Berdasarkan hasil analisis data dapat diketahui hasil penelitian yakni:

1. Berdasarkan pada hasil uji Mann Whitney U Test untuk menguji dua sampel independen dengan menggunakan bantuan program SPSS 16 for windows, menunjukkan bahwa hipotesis 1 diterima yakni, Adanya pengaruh pelatihan empati melalui kartu ekspresi emosi terhadap perilaku menolong dan perilaku agresif pada kelompok eksperimen dan kelompok kontrol.

2. Berdasarkan pada hasil analisis melalui Mann Whitney U Test untuk menguji dua sampel independen dengan menggunakan bantuan program SPSS 16 for windows, yang menunjukkan bahwa hipotesis 2 diterima. Yakni, Adanya pengaruh positif pelatihan empati melalui kartu ekspresi emosi terhadap perilaku menolong anak prasekolah.

3. Dari hasil analisis melalui Mann Whitney U Test untuk menguji dua sampel independen dengan menggunakan bantuan program SPSS 16 for windows, bahwa hipotesis 3 diterima, yakni Adanya pengaruh negatif pelatihan empati melalui kartu ekspresi emosi terhadap perilaku agresif anak prasekolah.

Hasil analisis menunjukkan Adanya pengaruh pelatihan empati melalui kartu ekspresi emosi terhadap perilaku menolong dan perilaku agresif pada kelompok eksperimen dan kelompok kontrol. Artinya pada kelompok eksperimen yang dikenai perlakuan berupa pelatihan empati mengalami perubahan perilaku. Perubahan perilaku tersebut adalah perilaku menolong yang lebih baik daripada kelompok kontrol. Sedangkan pada perilaku agresif, kelompok eksperimen menunjukkan perilaku agresif yang lebih rendah daripada kelompok kontrol. Hal ini diketahui dari pengetahuan mengenai perilaku menolong yang lebih baik pada kelompok eksperimen daripada kelompok kontrol yang menunjukkan bahwa kelompok eksperimen memiliki kemampuan empati yang lebih baik daripada kelompok kontrol setelah pelatihan empati melalui kartu ekspresi emosi dilakukan.

Hal tersebut diperkuat dengan penyataan dari Aronfeed (Eisenberg, 1989) ${ }^{29}$ bahwa pada awalnya empati diperoleh melalui kondisioning atau asosiasi, dimana secara berulang-ulang rasa senang atau rasa sakit pada anak dipasangkan dengan ekspresi orang lain tentang perasaan tersebut. Empati diukur dengan melakukan tes dimana kepada anak disajikan cerita atau rangkaian gambar yang mengandung informasi tentang kondisi perasaan orang lain (misalnya anak yang menangis ditinggal ibunya pergi). Kemudian mereka diminta memberi respon, verbal atau nonverbal (dengan menunjuk gambar ekspresi wajah) tentang apa yang mereka rasakan. Anak-anak tersebut akan diberikan skor empatis jika mereka menunjukkan perasaan yang sama dengan situasi tokoh yang ditunjukkan.

\footnotetext{
${ }^{29}$ Taufik, Empati: Pendekatan Psikologi........
} 
Beberapa diantara perubahan penting dalam perkembangan emosi pada masa kanakkanak awal adalah meningkatnya kemampuan untuk membicarakan emosi diri dan orang lain dan peningkatan pemahaman tentang emosi ${ }^{30}$. Pada rentang usia 2-4 tahun, terjadi penambahan yang pesat mengenai jumlah istilah yang digunakan untuk menggambarkan emosi. Mereka juga mulai belajar mengenai penyebab dan konsekuensi dari perasaanperasaan yang dialami ${ }^{31}$.

Masa prasekolah anak berada pada tingkatan pertama yang disebut dengan "moralitas prakonvensional". Dalam hal ini, anak tunduk pada kendali eksternal. Pada tahap ini, anak berorientasi pada kepatuhan dan hukuman. Moralitas satu tindakan dinilai atas dasar akibat fisiknya. Anak hanya mengetahui bahwa aturan ditentukan oleh adanya kekuasaan yng tidak dapat diganggu gugat. Selanjutnya anak masih mendasarkan di luar individu, namun sudah memperhatikan alasan perbuatannya. Oleh karena itu, kondisi moral anak yang seperti ini memungkinkan para pendidik dapat menerapkan perilaku disiplin pada anak usia prasekolah sebagai upaya membimbing anak untuk mengetahui perilaku mana yang baik dan manayang buruk, serta mendorongnya untuk berperilaku sesuai dengan standar-standar ini. ${ }^{32}$

Ketika menginjak usia 4-5 tahun, anak-anak mulai menunjukkan peningkatan kemampuan dalam merefleksi emosi. Mereka juga mulai memahami bahwa kejadian yang sama dapat menimbulkan perasaan yang berbeda terhadap orang yang berbeda. Lebih dari itu, mereka juga mulai menunjukkan kesadaran bahwa mereka harus mengatur emosi mereka untuk memenuhi standar sosial. Orangtua, guru dan orang dewasa lain di sekitarnya dapat membantu anak-anak memahami dan mengontrol emosi mereka. ${ }^{33}$ Pada orang dewasa dapat berbicara dengan anak-anak untuk membantu mereka mengatasi stres, kesedihan, kemarahan, atau perasaan bersalah. Belajar mengekspresikan emosi tertentu dan menutupi emosi yang lain, adalah pelajaran yang diperoleh dalam kehidupan sehari-hari anak-anak. Seorang anak yang marah jika harus menunggu sesuatu atau tertawa ketika melihat anak lain menangis karena terjatuh, dapat diajarkan untuk memahami perasaan orang lain. Seorang anak yang terlalu menonjolkan kemenangannya dalam sesuatu hal dapat diingatkan bahwa rasanya sangat menyedihkan bagi pihak yang kalah. ${ }^{34}$ Untuk mengembangkan kemampuan emosi tersebut salah satu hal yang dapat dilakukan adalah dengan membantu anak untuk memberi label terhadap emosi tersebut dan melatih anak berhadapan dengan emosi tersebut secara efektif sebagai upaya untuk mengoptimalkan kemampuan empati mereka.

Begitu pentingnya emosi bagi perkembangan anak. Santrock ${ }^{35}$ menyebutkan bahwa menurut pandangan fungsionalis, emosi adalah sesuatu yang bersifat relasional. Ekspresi emosi memiliki peran yang sangat penting dalam menunjukkan kepada orang lain apa yang dirasakan seseorang, mengatur perilaku seseorang dan sebagai poros dalam hubungan sosial. Emosi berkaitan dengan berbagai tujuan yang ingin dicapai oleh individu. Seorang anak yang dapat mengatasi berbagai halangan dalam mencapai sebuah tujuan akan merasakan kebahagiaan. Seorang anak yang terpaksa menyerah dan gagal mencapai suatu tujuan akan merasakan kesedihan, dan seorang anak yang harus menghadapi halangan yang sulit dalam

\footnotetext{
${ }^{30}$ Santrock, J. W, Perkembangan Anak (Jakarta: Erlangga, 2007), 17.

${ }^{31}$ Ibid

${ }^{32}$ Gustian, Mempersiapkan Anak Masuk Sekola (Jakarta: Erlangga, 2001)

${ }^{33}$ Santrock, Perkembangan Anak., 17.

${ }^{34}$ Ibid

${ }^{35}$ Ibid., 8
} 
proses mencapai suatu tujuan sering kali akan merasakan kemarahan. Santrock juga menyebutkan bahwa dua konsep kunci yang menunjukkan aspek terpenting dari perkembangan emosi adalah pengaturan emosi (emotional regulation) dan kompetensi emosi (emotional competence). Untuk mengembangkan kemampuan emosi tersebut salah hal yang dapat dilakukan adalah dengan membantu anak untuk memberi label terhadap emosi tersebut dan melatih anak berhadapan dengan emosi tersebut secara efektif sebagai upaya untuk mengoptimalkan kemampuan empati anak.

Saarni dalam Santrock menyebutkan bahwa untuk dapat dikatakan kompeten secara emosional, seseorang harus mengembangkan beberapa keterampilan yang berhubungan dengan konteks sosial, yaitu keterampilan untuk memahami tentang keadaan emosi yang dialami; mendeteksi emosi orang lain; menggunakan kosakata yang berhubungan dengan emosi dengan tepat pada konteks sosial dan budaya tertentu; sensitivitas empatik dan simpatik terhadap pengalaman emosional orang lain; memahami bahwa keadaan emosional di dalam tidak harus selalu berhubungan dengan ekspresi yang tampak di luar; coping adaptif terhadap emosi negatif dengan menggunakan strategi self-regulatory yang dapat mengurangi durasi dan intensitas dari emosi tersebut; menyadari bahwa ekspresi emosi memiliki peranan yang penting dalam hubungan interpersonal dan memandang bahwa keadaan emosi diri adalah cara seseorang mengatur emosinya. ${ }^{36}$

Hasil analisis yang menunjukkan hasil rerata peringkat perilaku menolong yang lebih tinggi pada kelompok eksperimen daripada kelompok kontrol menunjukkan bahwa adanya pengaruh positif pelatihan empati melalui kartu ekspresi emosi terhadap perilaku menolong anak prasekolah. Artinya, kelompok eksperimen yang melaksanakan pelatihan empati melalui kartu ekspresi emosi menunjukkan perilaku menolong yang lebih tinggi daripada kelompok kontrol yang tidak melaksanakan pelatihan empati. Hal ini menunjukkan bahwa anak prasekolah yang melaksanakan pelatihan empati telah memiliki kemampuan empati yang lebih baik daripada kelompok kontrol. Dengan memiliki kemampuan empati yang lebih baik, anak-anak akan memiliki kemampuan untuk menolong otang lain. Hal ini dibuktikan oleh Warnaken ${ }^{37}$ bahwa hasil akhir yang terbaik dari empati adalah munculnya perilaku menolong.

Menolong orang lain dan ditolong oleh orang lain jelas meningkatkan kesempatan bagi orang untuk dapat bertahan dan bereproduksi. Komponen afektif dari empati juga termasuk merasa simpatik tidak hanya merasakan penderitaan orang lain tetapi juga mengekspresikan kepedulian dan mencoba melakukan sesuatu untuk meringankan penderitaan mereka misalnya, individu yang memiliki empati tinggi lebih termotivasi untuk menolong seseorang teman daripada mereka yang memiliki empati rendah. Komponen kognitif dari empati tampaknya merupakan kualitas unik manusia yang berkembang hanya setelah individu melewati masa bayi, kognisi yang relevan termasuk kemampuan untuk mempertimbangkan sudut pandang orang lain, kadang-kadang disebut sebagai mengambil perspektif (perspective taking) yaitu mampu untuk menempatkan diri dalam posisi orang lain. ${ }^{38}$

Proses pembelajaran empati ini harus alami dan spontan untuk menunjukkan bahwa anak memiliki empati. Eliot dalam Beaty menjelaskan bahwa pembelajaran emosional dimulai dengan segera dalam bentuk peniruan. Bayi yang baru berumur beberapa jam saja

\footnotetext{
36 Ibid

${ }^{37}$ Taufik, Empati: Pendekatan Psikologi Sosial (Jakarta: PT Rajagrafindo Persada, 2012)

${ }^{38}$ Baron \& Byrne, Psikologi sosial, Alih Bahasa: Ratna Djuwita (Jakarta: Erlangga, 2005)
} 
mampu meniru ekspresi wajah tertentu atau isyarat tangan. Peniruan penting karena berfungsi sebagai dasar bagi pengembangan empati, kemampuan mengalami apa yang orang lain rasakan. ${ }^{39}$

Meskipun bayi yang baru lahir tampaknya memiliki dasar-dasar dari emosi ini, empati yang sebenarnya membutuhkan pengakuan sadar terhadap orang lain, yang belum muncul hingga berbulan-bulan atau bertahun-tahun kemudian. Hingga perkembangan kognitif ini telah terjadi, sang anak mungkin kesulitan mengungkapkan kepedulian empati terhadap orang lain karena sang anak masih terlalu egosentris sehingga kesulitan untuk melihat hal-hal dari sudut pandang orang lain. Karena empati yang masih rendah inilah, bayi dan balita sering kali salah memperlakukan hewan piaraan mereka. Anak-anak tidak tahu bahwa menarik telinga kucing atau meremas tubuh kucing dengan maksud untuk menggendongnya adalah perilaku yang menyakiti hewan. Memberi makan ayam dengan rumput, daun-daunan dan pasir. Memberi minum ayam dan burung dengan teh ataupun air pewarna sisa dari bermain merupakan bentuk perhatian mereka meskipun hal tersebut tidaklah tepat dan justru dapat menyakiti binatang. Sudut pandang egosentris ini akhirnya berubah sejalan dengan kematangan kognitif dan pengalaman

Riley, dkk dalam Beaty menjelaskan dua jenis kemampuan pengambilan-pespektif: sosial dan emosional. Pengambilan-perspektif sosial berarti anak harus merasakan apa yang orang lain inginkan. Pengambilan-perspektif emosional berarti anak harus merasakan bagaimana perasaan orang lain. Ini bukan merupakan tugas yang mudah bagi sebagian besar anak-anak kecil yang egosentris, meskipun beberapa tampaknya merasakannya secara intuitif. Tetapi sebagian besar anak mempelajari pengambilan perspektif dan empati melalui interaksi mereka dengan para teman sebaya dan melalui pencontohan dan pengajaran langsung dari orang dewasa. ${ }^{40}$

Penelitian telah menunjukkan bahwa ukuran komunitas dan peran wanita juga mempengaruhi kecenderungan perilaku menolong seorang anak. Anak-anak dari lingkungan pedesaan ketimbang perkotaan, dari kota kecil daripada kota besar, atau anak dengan ibu yang bekerja lebih cenderung menunjukkan kepedulian terhadap orang lain. ${ }^{41}$ Jika ibu bekerja di luar rumah, anak-anak sering kali mengemban tanggung jawab di usia dini. Mempelajari tugas-tugas membantu dan peduli sejak dini akan mengarahkan anak untuk memiliki perilaku menolong. Latar belakang keluarga penting untuk diketahui seorang pendidik untuk mengetahui sebab dari perilaku seorang anak dan berupaya untuk membantu anak untuk menyelesaikan permasalahan yang dialami.

Hal-hal yang dapat dilakukan untuk membantu anak memiliki empati adalah dengan memberikan contoh perilaku empati di ruang kelas. Guru harus memberikan teladan bagi anak-anak. Marion menjelaskan bahwa penelitian menunjukkan bahwa seorang anak sangat mungkin meniru teladan saat terkait dengan perilaku prososial. Pencontohan merupakan salah satu cara sangat ampuh untuk mendorong anak-anak bertindak secara prososial, dan guru harus konsisten dan mempraktikkan apa yang dikatakan ${ }^{42}$. Selanjutnya adalah membantu anak untuk menunjukkan kepedulian mereka sendiri. Hal ini dapat dilakukan dengan mendampingi

\footnotetext{
${ }^{39}$ Beaty, J. J., Observasi Perkembangan Anak Usia Dini (Jakarta: Kencana Prenadamedia Group, 2013), 170.

${ }^{40} \mathrm{Ibid}$

${ }^{41}$ Ibid., 172.

${ }^{42}$ Ibid., 173.
} 
anak saat bermain peran. Membacakan buku mengenai karakter mulia juga merupakan upaya untuk melatih empati anak. Langkah yang lain adalah dengan menggunakan cermin, boneka dan membuat gambat untuk mengetahui ekspresi dan perasaan diri maupun orang lain.

Hasil analisis yang menunjukkan hasil rerata peringkat perilaku agresif yang lebih rendah pada kelompok eksperimen daripada kelompok kontrol menunjukkan bahwa adanya pengaruh negatif pelatihan empati melalui kartu ekspresi emosi terhadap perilaku agresif anak prasekolah. Artinya, kelompok eksperimen yang melaksanakan pelatihan empati melalui kartu ekspresi emosi menunjukkan perilaku agresif yang lebih rendah daripada kelompok kontrol yang tidak melaksanakan pelatihan empati. Hal ini menunjukkan bahwa anak prasekolah yang melaksanakan pelatihan empati telah memiliki kemampuan empati yang lebih baik daripada kelompok kontrol. Dengan memiliki kemampuan empati yang lebih baik, anak-anak akan lebih mampu mengontrol emosi marah mereka dengan tidak melakukan perilaku agresif. Hal ini sesuai dengan yang disampaikan oleh Surbakti (2008) ${ }^{43}$ bahwa empati dapat menjadi upaya untuk mengatasi agresi pada anak. Menumbuhkan rasa empati dengan melatih pemikiran dan merasakan pikiran dan perasaan orang lain dianggap mampu mengatasi menurunkan perilaku agresif pada anak. Selain itu, Mergage menyatakan bahwa pemberian pelatihan empati akan mengurangi agresi. ${ }^{44}$

\section{Penutup}

Stimulasi aspek perkembangan sosial emosional untuk mengembangkan penguasaan kecakapan emosional dan kecakapan sosial perlu dilakukan oleh guru maupun orangtua terhadap anak. Hal ini dimaksudkan untuk membantu munculnya pemahaman emosi yang baik, berkembangnya kesadaran diri yang positif, serta mengarahkan anak mencapai pembentukan jati dirinya, sehingga dapat menjalin relasi positif dengan orang lain di lingkungan sekitarnya.

Adapun metode stimulasi yang diaplikasikan pada anak-anak perlu mempertimbangkan beberapa aspek perkembangan lainnya seperti perkembangan kognitif, dan juga dilakukan dengan metode-metode yang menyenangkan. Sehingga stimulasi tersebut dapat secara efektif diterima dan diterapkan oleh anak.

Berdasarkan hasil pengolahan data dan pembahasan pada bagian sebelumnya bisa ditarik kesimpulan bahwa pelatihan empati melalui kartu ekspresi emosi memberikan pengaruh positif pada perilaku menolong dan perilaku agresif pada kelompok eksperimen maupun kelompok kontrol. Pelatihan ini diketahui memberikan pengaruh positif pada perilaku menolong, dan sebaliknya berpengaruh negatif pada perilaku agresif pada anak usia pra sekolah.

\section{Daftar Rujukan}

Arikunto, S. Prosedur Penelitian Suatu Pendekatan Praktik, Jakarta: PT Rineka Cipta, 2006. Badan Pusat Statistik. Statistik Non Parametrik. Modul Diklat Fungsional Statistisi Tingkat Ahli

Baron \& Byrne. Psikologi sosial, Alih Bahasa: Ratna Djuwita, Jakarta: Erlangga, 2005.

\footnotetext{
${ }^{43}$ Santrock, J. W, Perkembangan Anak, (Jakarta: Erlangga, 2012)

${ }^{44}$ Goleman, D., Emotional Intelligence Kecerdasan Emosional : Mengapa EI Lebih Penting dari IQ. Alih Bahasa: T. Hermaya (Jakarta: Gramedia, 2002)
} 
Beaty, J. J. Observasi Perkembangan Anak Usia Dini, Jakarta: Kencana Prenadamedia Group, 2013.

Dayakisni, T \& Hudaniah. Psikologi Sosial, Malang: UMM Press, 2006.

Faturochman. Pengantar Psikologi Sosial, Yogyakarta: Pustaka Book Publishing, 2006.

Goleman, D. Emotional Intelligence Kecerdasan Emosional: Mengapa EI Lebih Penting dari IQ, Alih Bahasa: T. Hermaya, Jakarta: Gramedia, 2002.

Gustian. Mempersiapkan Anak Masuk Sekolah, Jakarta: Erlangga, 2001.

Hurlock, E. B. Psikologi Perkembangan: Suatu Pendekatan Sepanjang Rentang Kehidupan, Jakarta: Erlangga, 2004.

Indonesia Heritage Foundation. 9 Pilar Karakter, Jakarta: Gapprint, 2010.

Massardi, S \& Yudhistira. Pendidikan Karakter dengan Metode Sentra, Jakarta: Esmass, 2012

Prasetyo, B \& Jannah, L. M. Metode Penelitian Kuantitatif, Jakarta: PT RajaGrafindo Persada, 2007.

Pusat Bahasa. Kamus Besar Bahasa Indonesia edisi ke-4, Departemen Pendidikan Nasional, Jakarta: PT Gramedia Pustaka Utama, 2008.

Sabiq, Z \& Djalali, M. A. Kecerdasan Emosi, Kecerdasan Spiritual dan Perilaku Prososial Santri Pondok Pesantren Nasyrul Ulum Pamekasan. Persona, Jurnal Psikologi Indonesia, Vol I, No. 2, 53-65, 2012.

Santrock, J. W. Perkembangan Anak, Jakarta: Erlangga, 2007.

-------, Perkembangan Anak, Jakarta: Erlangga, 2012.

Sobur, A. Psikologi Umum, Jakarta: Rajagrafindo, 2000.

Tanaya, K, K \& Farid M. Pengaruh Cerita Moral Terhadap Perilaku Prososial Anak. Persona, Jurnal Psikologi Indonesia, Vol. 2, 84-89, 2013.

Taufik. Empati: Pendekatan Psikologi Sosial, Jakarta: PT Rajagrafindo Persada, 2012.

Walgito, B. Pengantar Psikologi Umum, Yogyakarta: Andi Offset, 2004. 